\title{
Analisis Kebijakan Luar Negeri Vanuatu Dalam Mendukung ULMWP Untuk Memisahkan Diri Dari Indonesia
}

\author{
M. Syaprin Zahidi \\ Prodi Hubungan Internasional, Universitas Muhammadiyah Malang \\ Email: syaprin123@umm.ac.id
}

\begin{abstract}
Vanuatu as one of the countries in the South Pacific Region has become a country that seems very diligent in criticizing Indonesia in international forums relating to the issue of violations of human rights in Papua. This was seen from 1982 when Vanuatu did not yet have diplomatic relations with Indonesia and then continued in 2014 when Vanuatu Prime Minister Moana Carcasses Katokai Kalosil at the 25th UN Human Rights Summit, delivered a speech urging the international community to support the independence of the Papuan people. This article argues that what was done by Vanuatu was inseparable from Vanuatu's domestical politic which the majority supported Papuan independence so that to frame the argument this article would use Graham T Allison's Organizational Process approach and adaptive model of foreign policy from Rosenau
\end{abstract}

Keywords: Indonesia, ULMWP, Vanuatu

\begin{abstract}
Abstrak
Vanuatu sebagai salah satu negara di Kawasan Pasifik Selatan menjadi negara yang terlihat selalu mengkritik Indonesia di forum internasional Berkaitan dengan isu pelanggaran Hak Asasi Manusia di Papua. Hal ini terlihat mulai dari tahun 1982 ketika Vanuatu belum memiliki hubungan diplomatik dengan Indonesia lalu berlanjut pada tahun 2014 ketika Perdana Menteri Vanuatu Moana Carcasses Katokai Kalosil pada sidang Tinggi HAM PBB yang ke-25 menyampaikan pidato yang mendesak masyarakat internasional untuk mendukung kemerdekaan rakyat Papua. Tulisan ini berpendapat bahwa apa yang dilakukan oleh Vanuatu tersebut tidak terlepas dari politik domestik Vanuatu yang mayoritas mendukung kemerdekaan Papua sehingga untuk mengkerangkai argumen tersebut tulisan ini akan menggunakan pendekatan proses organisasi dari Graham T Allison dan adaptive model of foreign policy dari Rosenau. Hal yang baru dari tulisan ini menurut penulis adalah pendekatan yang digunakan untuk mengkerangkai keputusan Vanuatu dalam mendukung kemerdekaan Papua.
\end{abstract}

Kata kunci: Indonesia, ULMWP, Vanuatu 


\section{Pendahuluan}

Kebijakan luar negeri yang diambil oleh suatu negara terhadap suatu isu internasional tentunya tidak dapat dilepaskan dari proses pengambilan keputusan di dalam negara tersebut (Mintz \& DeRouen, 2010). Hal ini pula yang bisa dicermati dari kebijakan luar negeri Vanuatu yang mendukung United Liberation Movement for West Papua (ULMWP) untuk memisahkan diri dari Indonesia. Vanuatu dalam mendukung kemerdekaan Papua telah meminta kepada negara-negara yang ada di Pacific Islands Forum (PIF) untuk mendukung kebijakannya dalam menyampaikan resolusi ke Majelis Umum Perserikatan Bangsa-Bangsa (UNGA) untuk memberikan hak kepada Papua dalam menentukan nasibnya sendiri (Observer, 2018). Walaupun pada akhirnya tindakan Vanuatu tersebut direspon oleh Indonesia sebagai sebuah tindakan yang tidak berdasar atau tidak dapat dipahami nalar sehat (Davidson, 2018).

Dukungan Vanuatu terhadap kemerdekaan Papua bisa dikatakan menjadi suatu dukungan yang konsisten dilakukan oleh Vanuatu sejak beberapa tahun terakhir diantaranya adalah pada tahun 2003 ketika masa pemerintahan Perdana Menteri Barak Sope, Vanuatu menjadi tuan rumah acara gerakan kemerdekaan Papua di Port Villa (Goissler, 2017). Kemudian pada tahun 2014 di masa Perdana Menteri Moana Carcasses Katokai Kalosil Vanuatu secara resmi mengecam tindakan pelanggaran Hak Asasi Manusia yang dilakukan oleh Pemerintah Indonesia di Papua pada sidang Tinggi HAM PBB yang ke-25 (Pacific Media Center, n.d.).

Pada tahun 2016 dan 2017 Vanuatu kembali mengemukakan masalah Papua di Forum Perserikatan Bangsa-Bangsa walaupun pada akhirnya upaya Vanuatu tersebut mendapatkan tentangan dari para diplomat Indonesia di masing-masing tahun tersebut (Prihantoro Nugroho, 2017). Dukungan terkini Vanuatu terhadap ULMWP dalam pemerdekaan Papua dilakukan pada tahun 2019 yaitu ketika delegasi Vanuatu pada tanggal 25 Januari bertemu dengan Komisioner Tinggi HAM PBB di Jenewa, Swiss untuk membicarakan perkembangan masalah HAM di Vanuatu yang dikenal sebagai Universal Periodic Review . Ternyata, tanpa sepengetahuan dari komisioner tinggi HAM PBB Vanuatu memasukkan nama Benny Wenda dalam Delegasinya. Benny Wenda sendiri merupakan ketua ULMWP (CNN Indonesia, 2019). 
Dalam setiap forum internasional isu yang dibawa oleh Vanuatu selalu berkenaan dengan Melanesia Connection dan Melanesia Renaissance. Dalam pandangan penulis, ini menjadi suatu isu yang selalu dikemukakan oleh Vanuatu karena berkaitan dengan rasa persaudaraan mereka pada masyarakat Papua yang sama-sama beretnis Melanesia. Tidak mengherankan jika kemudian Vanuatu terlihat sangat konsisten di Forum Internasional untuk selalu membawa isu pelanggaran HAM di Papua ini. Vanuatu juga memiliki cita-cita ingin menjadi pemimpin bagi etnis Melanesia. Sehingga, menjadi rasional jika kita melihat kebijakan Vanuatu yang selalu konsisten dalam menggugat Indonesia di berbagai forum internasional terkait isu pelanggaran HAM di Papua (Bagus Thomas, 2016).

Disisi lain sangat terlihat jelas keinginan dari Vanuatu untuk menjadi leading actor dalam membawa masalah pelanggaran HAM di Papua ini ke dalam isu internasional. Semangat Melanesia renaissance menjadi instrumen Vanuatu untuk selalu mendorong masyarakat internasional agar mendukung Vanuatu untuk menyuarakan kemerdekaan Papua. Sehingga tidak begitu mengejutkan jika Vanuatu terus menerus membawa masalah pelanggaran HAM di Papua ini ke dunia internasional

karena

ini

menjadi

keuntungan politik dalam forum internasional bagi Vanuatu yang suaranya pasti akan selalu di dengar oleh masyarakat internasional jika membawa isu kemerdekaan Papua (Bagus Thomas, 2016).

Tindakan-tindakan yang dilakukan oleh Vanuatu tersebut merupakan output dari proses pengambilan kebijakan luar negeri di dalam negerinya. Menjadi penting kemudian menurut penulis untuk menganalisis lebih dalam proses pengambilan keputusan dalam kebijakan luar negeri Vanuatu yang mendukung ULMWP di forum-forum Internasional.

\section{Review Literatur}

Dalam Kajian Hubungan Internasional ada banyak sekali pendekatan yang biasa digunakan dalam mengkaji kebijakan luar negeri suatu negara sebagaimana diungkapkan oleh Kesgin bahwa kajian analisis kebijakan luar negeri merupakan suatu kajian yang kaya literatur dan beragam dalam analisisnya (Kesgin, 2011). Bagaimana biasanya para pengkaji hubungan internasional mencoba untuk melihat analisis kebijakan luar negeri suatu negara? Jawaban paling sederhana diungkapkan oleh Hudson \& Vore dalam 
artikelnya yang berjudul Foreign Policy Analysis Yesterday, Today, and Tomorrow mereka berdua menyebut bahwa para pengkaji hubungan internasional biasanya menganalisis kebijakan luar negeri suatu negara dengan memposisikan negara tersebut sebagai aktor yang monolit sebagai contoh diungkapkan olehnya ketika melihat kebijakan luar negeri Amerika Serikat maka baik itu (Presiden, Menteri Luar Negeri, Central Intelligence Agency dianggap menjadi satu kesatuan) (Hudson \& Vore, 2006).

Kajian analisis kebijakan luar negeri juga dapat dilihat dari jenis pertanyaan yang diajukan sebagaimana di ungkapkan oleh Doty dalam artikelnya yang berjudul Foreign Policy as Social Construction: A Post-Positivist Analysis of U.S. Counterinsurgency Policy in the Philippines. Ia menyatakan dalam pendekatan konvensional analisis kebijakan luar negeri suatu negara biasanya fokus untuk menjawab pertanyaan mengapa. Jawaban yang biasa digunakan adalah dengan menjelaskan posisi dari negara tersebut dalam hirarki kekuatan internasional, tarik menarik kepentingan pada aktor-aktor di dalam negara tersebut atau penjelasan mengenai persepsi dari para pengambil kebijakan di dalam negara tersebut (Doty, 2006).
Apabila pertanyaannya adalah bagaimana, biasanya yang akan dijadikan fokus menurut doty adalah pada proses bagaimana masing-masing varian dalam kebijakan luar negeri mampu mengkonstruksi posisinya masing-masing. Jadi yang dilihat bukan lagi pada mengapa misalkan Amerika Serikat memberikan kemerdekaan pada Filipina tetapi bagaimana Amerika Serikat mengkonstruksi dirinya sehingga bersedia memberikan kemerdekaan kepada Filipina (Doty, 2006).

Adapun dalam penelitian ini peneliti akan menggunakan Proses perumusan kebijakan luar negeri yang dikemukakan oleh Graham $\mathrm{T}$ Allison dalam artikelnya yang berjudul Conceptual Models and the Cuban Missile Crisis. salah satu model yang dikenalkan oleh Allison yaitu organizational Process Model dalam model ini disebutkan bahwa Pemerintahan suatu negara dipandang sebagai sebuah organisasi besar yang dibentuk oleh unit-unit yang dalam mekanisme dan perannya masing-masing unit tersebut memiliki tanggung jawab atas bidangnya masing-masing (Allison, 1969).

Organisasi besar ini juga memiliki pemimpin yang akan mengambil 
keputusan akhir terhadap segala masalah atau isu yang dihadapi. meskipun, mungkin unit-unit tersebut tidak setuju dengan keputusan pemimpinnya namun karena mereka menjadi bagian dari organisasi besar itu maka mereka tidak dapat menolak keputusan dari pemimpinnya. Disebabkan oleh hal tersebut maka disebutkan bahwa sistem ini dianggap mirip dengan sistem feodal (Allison, 1969).

Model Proses Organisasi juga menekankan bahwa pembuatan keputusan kebijakan luar negeri bukanlah sematamata proses intelektual namun merupakan proses mekanis. Maksudnya adalah pembuatan keputusan merujuk kepada pembuatan keputusan yang lama di masa lalu, merupakan prosedur rutin yang berlaku atau yang dikenal dengan Standard Operating Procedure. Secara umum Allison juga berasumsi bahwa dengan menggunakan model proses organisasi maka dapat meramalkan apa yang terjadi pada suatu waktu dengan melihat kejadian pada waktu sebelumnya (Allison, 1969).

Model inilah yang akan peneliti gunakan untuk menjelaskan proses pengambilan keputusan di dalam negeri Vanuatu yang memiliki Standard Operating Procedure dalam perumusan kebijakan luar negerinya terutama yang terkait dengan dukungan Vanuatu terhadap kemerdekaan Papua.

Selain model proses organisasi milik Allison penelitian ini juga akan menggunakan adaptive model of Foreign Policy dari Rosenau. Dalam Adaptive model of Foreign Policy dijelaskan bahwa kebijakan luar negeri berada pada dua level yaitu lingkungan internal (politik domestik) dan lingkungan ekstenal (Hubungan dengan negara lain, Sistem Internasional, Isu internasional dan lainlain) yang pada akhirnya membuat negara tersebut harus berdaptasi dan memutuskan pilihan kebijakan luar negerinya (Rosenau, 1974a).

Dalam konteks penelitian ini peneliti akan menggunakan salah satu model dalam adaptive model of foreign policy yaitu preservative adaptation. Model ini menjelaskan tentang respon yang diberikan oleh suatu negara dalam menghadapi tuntutan atau dorongan dari aspek domestik dan internasional dengan kata lain kebijakan luar negeri yang dihasilkan oleh suatu negara merupakan hasil dari dorongan atau tuntutan internal (domestik) negara tersebut dan tuntutan/dorongan ekstenal terhadap negara tersebut (Rosenau, 1974b). 


\section{Metode Penelitian}

Penelitian ini menggunakan metode penelitian kualitatif. Penelitian Kualitatif merupakan penelitian yang tidak bisa dilepaskan dari paradigma non positivisme yang menjelaskan bahwa kebenaran tidak hanya berhenti pada fakta yang ada tetapi fokus pada makna yang terkandung dibalik fakta tersebut. Rumpun ilmu sosial bisa dikatakan menganut pendekatan kualitatif dalam setiap penelitiannya karena yang diteliti adalah manusia bukan benda sebagaiamana dalam penelitian kuantitatif (Aman, 2007).

Fokus penelitian ini yaitu pada proses pengambilan keputusan di dalam negeri Vanuatu untuk mendukung ULMWP dan sayap organisasinya (OPM) dalam memerdekakan Papua selain itu sebagai tambahan analisis penelitian ini juga membahas mengenai faktor internal dan eksternal yang menyebabkan Vanuatu pada akhirnya memutuskan untuk mendukung ULMWP memisahkan diri dari Indonesia. Berkaitan dengan hal tersebut maka data-data yang akan digunakan dalam penelitian ini semuanya didasarkan pada topik yang terkait dengan proses politik dalam negeri Vanuatu tentang isu ULMWP dan aspek ekstenal yang mendorong Vanuatu mendukung ULMWP. Adapun metode pengumpulan data yang digunakan adalah dengan melalui studi dokumentasi pada artikel, Policy Paper dan data-data lainnya yang terkait dengan kebijakan luar negeri Vanuatu untuk mendukung ULMWP.

Data-data tersebut tentunya terkait dengan kerangka teori yang penulis gunakan dalam penelitian ini yaitu model proses organisasi dari Graham $\mathrm{T}$ Allison dan Adaptive model of Foreign Policy dari Rosenau. Karena penulis memahami tidak semua data dapat digunakan dalam penelitian ini sehingga dibutuhkanlah proses triangulasi data. Triangulasi data sendiri dijelaskan oleh Norman K. Denkin sebagai penggabungan berbagai metode untuk mengkaji suatu fenomena dari sudut pandang dan perspektif yang berbeda $(\mathrm{H}$. Mudjia Rahardjo, 2010). Singkatnya menurut peneliti perlu ada verifikasi terlebih dahulu untuk semua data yang peneliti kumpulkan dalam melakukan penelitian ini apalagi peneliti melakukan studi dokumentasi dalam penelitian ini karena keterbatasan akses untuk melakukan penelitian langsung.

\section{Hasil dan Analisis}

Dalam menjabarkan tentang kebijakan luar negeri Vanuatu yang mendukung ULMWP maka menjadi penting menurut peneliti untuk mengetahui 
secara komprehensif tentang sistem pemerintahan dari Vanuatu termasuk di dalamnya Decision Making Process/Proses Pembuatan keputusan Vanuatu untuk mendukung ULMWP memisahkan diri dari Indonesia. Untuk itu dalam penelitian ini peneliti akan menjabarkan telebih dahulu secara detail tentang sistem pemerintahan Vanuatu, Mekanisme Proses Pengambilan keputusan di Vanuatu serta terakhir peneliti akan menjabarkan tentang output dari proses pengambilan keputusan di Vanuatu tersebut.

\section{Sistem Pemerintahan Vanuatu}

Vanuatu merupakan negara dengan sistem pemerintahan Republik Parlementer. Presiden berperan sebagai kepala negara dan Perdana Menteri berperan sebagai kepala pemerintahan. Vanuatu juga merupakan negara yang dipengaruhi oleh sistem pemerintahan yang dianut oleh Perancis dan Inggris hal ini bisa dipahami karena sebelumnya Vanuatu merupakan wilayah yang dikuasai oleh kedua negara tersebut. Vanuatu sendiri baru merdeka pada tahun 1980 .

Dalam perpolitikan domestik di Vanuatu terdapat dua partai yang mendominasi yaitu New Hebrides National Party (NHNP/Vanua'aku Pati-VP) dan Union Communautes des Nouvelles-
Hebrides (MANH). Selain dua partai tersebut sebenarnya masih ada satu partai lagi di Vanuatu yang juga menyaingi dominasi dua partai tersebut yaitu Graon mo Jastis Pati (Giay, 2019).

Presiden dalam sistem pemerintahan Vanuatu hanya berkedudukan sebagai simbol pemerintahan saja dan dipilih setiap lima tahun sekali oleh dua pertiga dari anggota parlemen dan dewan setempat. Presiden tidak memiliki kekuasaan apapun di Vanuatu dan dapat dilengserkan jika melakukan tindak pidana korupsi dan tindakan-tindakan lainnya yang dianggap merugikan negara. Sedangkan, Perdana Menteri memiliki kekuasaan yang lebih dari pada Presiden karena memiliki kewenangan untuk menjalankan pemerintahan. Secara umum sistem pemerintahan Vanuatu juga terhubung dengan kultur dan sejarah Melanesia. Vanuatu juga masih menganut sistem politik tradisional yang terbentuk dari unitunit kecil yang terdiri dari lima puluh sampai tiga ratus orang (Bagus Thomas, 2016).

Hal yang penting menurut peneliti terkait dengan sistem pemerintahan Vanuatu yaitu posisi Perdana Menteri yang lebih powerfull dibandingkan Presiden Vanuatu. Perdana Menteri Vanuatu 
merupakan pemimpin di Parlemen Vanuatu yang menganut sistem unikameral. Anggota Parlemen di Vanuatu terdiri dari 52 anggota yang dipilih empat tahun sekali. Parlemen di Vanuatu bisa dibubarkan jika 3/4 anggota setuju untuk dibubarkan. Perdana Menteri disisi lain memiliki kewenangan untuk menunjuk Dewan Menteri yang nantinya akan membentuk pemerintahan eksekutif dan membantu Perdana Menteri dalam menjalankan pemerintahannya (Usman, 2017).

Dalam sejarah pemerintahan di Vanuatu sampai dengan tahun 2019 sudah ada 10 kabinet yang terbentuk. Di Vanuatu Dewan Menteri terdiri dari perwakilan partai-partai serta ditambah dua anggota independen dari Parlemen Vanuatu. Hal ini menunjukkan bahwa proses demokrasi di Vanuatu sangat dinamis karena pemerintahan disusun berdasarkan komposisi partai-partai yang bersaing dalam pemilu. Selain komposisi kabinet yang biasanya selalu terdiri dari multipartai hal lain yang cukup menarik yaitu tentang amandemen konstitusi yang diiizinkan apabila disetujui paling tidak oleh $3 / 4$ anggota parlemen di Vanuatu (Usman, 2017).

Pemerintah di Vanuatu juga bertanggung jawab terhadap eksistensi dari kepolisian di Vanuatu. Disisi lain, Pemerintah juga mengakui peranan dari kepala Suku di Vanuatu. Sehingga bisa dibilang secara eksplisit Pemerintah Vanuatu menghargai local wisdom yang mereka anut yang menyebabkan peranan dari unsur Melanesian brotherhood menjadi hal penting bagi pemerintah Vanuatu karena secara umum suku-suku yang hidup di Vanuatu sangat menjunjung tinggi rasa persaudaraan di antara mereka.

Berikut adalah Gambar dari sistem pemerintahan di Vanuatu:

Gambar 1. Sistem Pemerintahan di Vanuatu

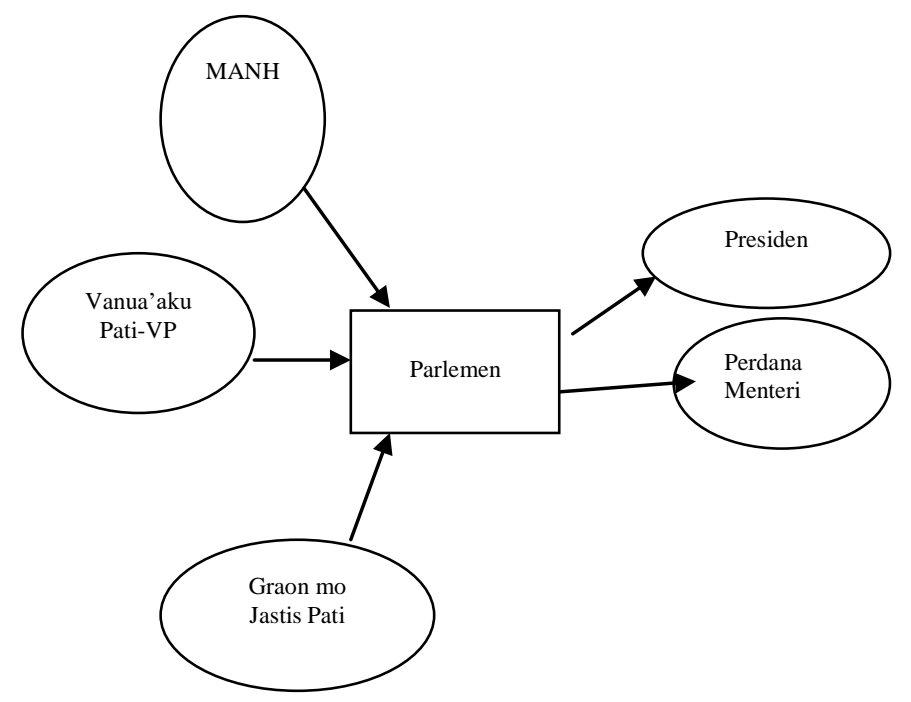

Sumber : Desain Pribadi

Berdasarkan pada gambar tersebut dapat terlihat jelas bahwa dalam pemerintahan di Vanuatu yang berbentuk Republik Parlementer partai-partai politik sangat berperan dalam parlemen. Adapun Peranan Presiden tidak telalu maksimal karena kedudukan dari Presiden hanyalah 
sebagai simbol kepala negara di Vanuatu sedangkan Perdana Menteri memiliki peranan yang lebih maksimal dibandingkan dengan Presiden.

\section{Mekanisme Proses Pengambilan \\ Keputusan di Vanuatu}

Kebijakan suatu negara baik dalam konteks domestik maupun luar negeri tentunya tidak akan bisa dilepaskan dari unit-unit pemerintahan yang terdapat didalamnya. Unit-unit tersebut pasti memiliki persepsi masing-masing tentang suatu isu. Pendapat dari masing-masing unit tersebutlah yang pada akhirnya akan menjadi pertimbangan bagi siapapun pengambil keputusan di dalam negara tersebut. Hal tersebut juga dapat kita lihat pada proses pengambilan keputusan di Vanuatu terkait dengan dukungan terhadap ULMWP.

Mekanisme proses pengambilan keputusan di Vanuatu secara umum melibatkan beberapa aktor penting yaitu Partai-partai yang mendominasi seperti Vanua'aku Pati-VP dan beberapa partai lainnya yang dominasinya tidak sekuat Vanua'aku Pati-VP sehingga isu yang dikembangkan oleh partai ini secara tradisional pada akhirnya akan menjadi isu nasional di Vanuatu. Biasanya isu yang dibawa oleh Vanua'aku Pati-VP akan segera menjadi isu diparlemen. Parlemen akhirnya akan menjadi tempat bagi para anggota-anggota parlemen untuk membahas isu-isu penting yang terkait dengan Vanuatu. Di sisi lain Presiden hanya berperan sebagai pemilik kekuasaan yang dipilih secara seremonial oleh 2/3 anggota parlemen. Adapun Perdana Menteri memiliki kekuasaan yang penuh karena menjalankan pemerintahan dan dipilih oleh mayoritas anngota Parlemen di Vanuatu (Morgan, 2008).

Dalam isu dukungan Vanuatu terhadap ULMWP dapat dikatakan ini bermula dari visi partai yang dominan di Vanuatu yaitu Vanua'aku Pati-VP atau VP yang fokus pada isu-isu kemerdekaan Papua karena partai ini menganut paham sosialisme Melanesia yang merupakan implementasi dari Melanesia Way. VP sendiri merupakan partai yang fokus pada Melanesian brotherhood pada aspek kebijakan luar negerinya. Sehingga fokus advokasi pada dekolonialisasi atas koloni Melanesia merupakan tujuan utama dari partai ini (Morgan, 2008).

Visi dari partai VP ini sejalan dengan sistem pemerintahan Vanuatu yang terhubung dengan budaya dan sejarah Melanesia. Hal inilah yang akhirnya memuluskan isu ini untuk dibahas di Parlemen Vanuatu. Apalagi anggota- 
anggota parlemen didominasi oleh anggota partai dari VP. Ketika pada akhirnya parlemen Vanuatu memutuskan untuk mendukung ULMWP memisahkan diri dari Indonesia. Presiden pada akhirnya menyetujui keputusan tersebut dan Perdana Menteri Vanuatu melaksanakan hasil dari keputusan parlemen Vanuatu. Sehigga menurut peneliti menjadi wajar jika kita melihat statement-statement dari Pemerintah Vanuatu selalu mendukung ULMWP di setiap forum-forum internasional.

\section{Output dari Proses Pengambilan}

\section{Keputusan di Vanuatu}

Output dari keputusan Vanuatu untuk mendukung ULMWP memisahkan diri dari Indonesia dapat dilihat dari penggunaan isu etnis dalam setiap kegiatan diplomatik yang dilakukan oleh Perdana Menteri Vanuatu contohnya ketika era pemerintahan Barak Sope yang secara terang-terangan mendukung Organisasi Papua Merdeka (OPM) di Indonesia dan hal itu tidak hanya diungkapkan dalam bentuk statement resmi namun Barak Sope juga mengijinkan ULMWP untuk memiliki kantor perwakilan yaitu West Papua People's Representative Office di Port Villa. Selain itu parlemen di Vanuatu juga menyampaikan mosi dukungan bagi gerakan Organisasi Papua Merdeka (OPM) di Papua (Morgan, 2008).

Dukungan terhadap ULMWP juga diperjuangkan oleh Vanuatu di kawasan pasifik selatan ini terbukti dengan upaya Vanuatu untuk melobi negara-negara di organisasi Melanesian Spearhead Group (MSG) agar menerima ULMWP menjadi anggota di organisasi tersebut. Tentunya menurut peneliti upaya ini benar-benar menjadi bukti dukungan yang massif dari Vanuatu terhadap ULMWP (O'neill, 2014).

Dukungan Vanuatu juga dapat dilihat pada tahun 2014 ketika Perdana Menteri Vanuatu Moana Carcasses Katokai Kalosil pada sidang Tinggi HAM PBB yang ke-25 menyampaikan pidato yang mengklaim bahwa pada tahun 1969 ketika Papua menjadi bagian dari Indonesia melalui pemungutan pendapat rakyat (pepera) adalah suatu settingan dari pemerintah Indonesia. Dukungan Vanuatu dilanjutkan lagi pada tahun 2016 dan 2017 Vanuatu dengan beberapa negara pasifik selatan lainnya kembali mengangkat masalah Papua ini di forum PBB walaupun akhirnya dibantah oleh Diplomat muda Indonesia yaitu Nara Rakhmatia Masista dan Ainan Nuran (Observer, 2018). 
Terakhir Pada tanggal 25 Januari 2019 lalu. Ada suatu kejadian yang cukup mengejutkan karena pada pertemuan khusus antara Vanuatu dengan Komisioner Tinggi Hak Asasi Manusia Perserikatan Bangsa-Bangsa (KTHAM PBB) di Jenewa, Swiss yang membahas tentang UPR (Universal Periodic Review), ternyata digunakan oleh Delegasi Vanuatu untuk mengajak Benny Wenda. Benny wenda merupakan pemimpin United Liberation Movement for West Papua (ULMWP) atau Gerakan Pembebasan Papua Barat. Dalam pertemuan tersebut Benny Wenda menyerahkan petisi yang diklaim sudah ditanda tangani oleh 1,8 juta masyarakat di Papua dari total total 2,5 juta masyarakat Papua kepada Komisioner Tinggi HAM PBB Michelle Bachelet. Dalam petisi tersebut disebutkan bahwa masyarakat Papua dibawah kendali pemerintah Indonesia tidak mendapatkan kebebasan dan meminta kepada KTHAM PBB untuk turun tangan menyelesaikan masalah tersebut (CNN Indonesia, 2019).

\section{Aspek Internal dan Ekstenal Kebijakan \\ Luar Negeri Vanuatu Dalam Mendukung ULMWP}

Aspek internal dan ekstenal dalam kebijakan luar negeri Vanuatu yang mendukung ULMWP untuk memisahkan diri dari Indonesia secara singkat dapat dijabarkan sebagai berikut:

a. Aspek Internal

Dalam aspek internal secara komprehensif sebenarnya sudah dijelaskan dalam penjelasan mengenai politik domestik di Vanuatu yang pada akhirnya menghasilkan suatu konsensus dari partai-partai besar di Vanuatu yang mendorong pemerintahnya untuk mendukung ULMWP bahkan parlemen Vanuatu pada tahun 2010 memutuskan untuk mengadopsi Rancangan undangundang Wantok Blong Yumi yaitu undang-undang yang menegaskan dukungan Vanuatu terhadap kemerdekaan Papua dari Indonesia (CNN Indonesia, 2019).

b. Aspek Eksternal

Dalam aspek eksternal yang mendorong Vanuatu pada akhirnya mendukung ULMWP adalah lobby dari Benny Wenda sebagai perwakilan ULMWP kepada pemerintah Vanuatu untuk mendukung gerakan ULMWP dalam memisahkan diri dari Indonesia.

Hal ini ditegaskan oleh Benny Wenda dalam statementnya yang 
mengatakan bahwa kami berusaha untuk melobby negara-negara anggota PBB salah satunya adalah Vanuatu untuk mendukung kemerdekaan kami karena kami sama-sama memiliki ikatan Melanesian Brotherhood (Suara Papua, 2019)

Secara singkat bisa dijelaskan bahwa keputusan Vanuatu yang pada akhirnya mendukung ULMWP untuk memisahkan diri dari Indonesia memang tidak bisa dilepaskan dari proses politik domestiknya sebagai faktor internal dan dorongan ULMWP dalam kerangka melanesian brotherhood sebagai faktor eksternal.

\section{Kesimpulan}

Berdasarkan pada pembahasan diatas ada beberapa hal penting yang bisa disimpulkan diantaranya adalah Kondisi politik di Vanuatu pada kenyataannya tidak dapat dilepaskan dari dominasi satu partai besar yaitu partai Vanua'aku PatiVP yang memang memiliki posisi penting dalam perpolitikan di Vanuatu hal ini tampak dalam visi partai ini ketika mendukung gerakan Melanesian way yang implementasinya adalah mendukung ULMWP ternyata menjadi hal penting dalam perpolitikan di Vanuatu. Hal tersebut terbukti ketika isu ini menjadi isu yang dibahas dalam parlemen di Vanuatu dan di justifikasi oleh Presiden Vanuatu dan Perdana Menteri Vanuatu.

Hal ini diperkuat lagi dengan kondisi sistem pemerintahan di Vanuatu yang terpengaruh oleh Melanesian Brotherhood dan dorongan ULMWP yang terus menerus meminta bantuan Vanuatu dalam setiap kegiatan mereka, sehingga isu kemerdekaan di Papua tentunya akan secara langsung mendapatkan respon yang positif di Vanuatu. Hal ini pada akhirnya dapat dilihat dari dukungan pemerintah Vanuatu yang massif di dunia internasional terhadap ULMWP. Walaupun menurut peneliti isu ini akan selalu di bawa oleh Pemerintah Vanuatu karena dengan menggunakan isu ini maka Vanuatu memiliki isu menarik yang bisa dibahas di forum-forum internasional karena jika membahas isu di dalam negeri Vanuatu tidak ada yang menarik dan penting untuk dibahas.

\section{Referensi}

Allison, G. T. (1969). Conceptual Models and the Cuban Missile Crisis. American Political Science Review, 63(3), 689-718. https://doi.org/10.1017/S0003055400 25853X

Aman. (2007). Metodologi Penelitian 
Kualitatif. Mahasiswa Pendidikan

Sosiologi, 1-11. Retrieved from

http://webcache.googleusercontent.co

$\mathrm{m} / \mathrm{search}$ ?q=cache:http://eprints.umsi

da.ac.id/1447/1/PDF\%2520of\%2520

MAKNA\%2520METODOLOGI\%25

20DAL\%2520AM\%2520PENELITI

AN\%2520VIVI.docx

Bagus Thomas, T. P. (2016). Kepentingan

Vanuatu Dalam Usaha Pemerdekaan

Papua. Jurnal Analisis Hubungan

Internasional, 5(2). Retrieved from

http://journal.unair.ac.id/download-

fullpapers-jahiff7d4e27a0full.pdf

CNN Indonesia. (2019). KTHAM PBB

Kaget Benny Wenda "Menyusup" dalam Delegasi Vanuatu. Retrieved

March 17, 2019, from

https://www.cnnindonesia.com/intern

asional/20190131084205-106-

365278/ktham-pbb-kaget-benny-

wenda-menyusup-dalam-delegasi-

vanuatu

CNN Indonesia. (2019). Vanuatu, "Si

Kecil" di Pasifik Pendukung

Kemerdekaan Papua.

https://www.cnnindonesia.com/intern

asional/20191002160752-113-

436136/vanuatu-si-kecil-di-pasifik-

pendukung-kemerdekaan-papua

Davidson, H. (2018). Indonesia accuses

Vanuatu of "inexcusable" support for

West Papua | World news | The
Guardian. Retrieved March 11, 2019,

from

https://www.theguardian.com/world/2

018/oct/03/indonesia-accuses-

vanuatu-of-inexcusable-support-for-

west-papua

Doty, R. L. (2006). Foreign Policy as

Social Construction: A Post-Positivist

Analysis of U.S. Counterinsurgency

Policy in the Philippines.

International Studies Quarterly,

37(3), 297.

https://doi.org/10.2307/2600810

Giay, E. (2019). Pemilu mendekat, parpol

terbesar di Vanuatu ancang-ancang.

Retrieved December 1, 2019, from

https://www.jubi.co.id/pemilu-

mendekat-parpol-terbesar-di-vanuatuancang-ancang/

Goissler, W. (2017). Para Pemimpin Pro

Papua Merdeka Berkumpul di

Vanuatu. Retrieved March 17, 2019,

from

http://www.satuharapan.com/read-

detail/read/para-pemimpin-pro-papua-

merdeka-berkumpul-di-vanuatu

H. Mudjia Rahardjo. (2010). Triangulasi

dalam Penelitian Kualitatif.

https://doi.org/10.1360/zd-2013-43-6-

1064

Hudson, V. M., \& Vore, C. S. (2006).

Foreign Policy Analysis Yesterday,

Today, and Tomorrow. Mershon 
International Studies Review, 39(2),

209. https://doi.org/10.2307/222751

Kesgin, B. (2011). Foreign policy analysis.

In 21st Century Political Science: A

Reference Handbook.

https://doi.org/10.4135/97814129793

$51 . \mathrm{n} 40$

Mintz, A., \& DeRouen, K. (2010).

Understanding foreign policy:

Decision making. In Understanding

Foreign Policy: Decision Making.

https://doi.org/10.1017/CBO9780511

757761

Morgan, M. G. (2008). THE ORIGINS

\section{AND EFFECTS OF PARTY}

FRAGMENTATION IN

VANUATU. In Political Parties in

the Pacific Islands. ANU Press.

O’neill, P. (2014, July 2). MSG opens door

for Papua membership. Solomon Star.

Retrieved from

http://www.solomonstarnews.com/ind

ex.php/component/content/article/147

-news1/regional/2804-msg-opens-

door-for-papua-membership

Observer, S. (2018). Vanuatu seeks

support for West Papua - Vanuatu

Independent. Retrieved March 11,

2019, from

https://vanuatuindependent.com/2018

/08/13/vanuatu-seeks-support-west-

papua/

Pacific Media Center. (n.d.). Vanuatu PM blasts Indonesian human rights

violations in West Papua. Retrieved

March 17, 2019, from

http://www.pmc.aut.ac.nz/articles/van

uatu-pm-blasts-indonesian-human-

rights-violations-west-papua

Prihantoro Nugroho, B. (2017). Isu

Separatisme Papua di PBB dan

Bantahan dari Diplomat Muda RI.

Retrieved March 17, 2019, from

https://news.detik.com/berita/d-

3677601/isu-separatisme-papua-di-

pbb-dan-bantahan-dari-diplomat-

muda-ri

Rosenau, J. N. (1974). Comparing Foreign

Policy: Theories, Findings and Methods. Sage Publications.

Suara Papua. (2019). Benny Wenda: Tugas Kami Melakukan Lobby pada Negara-negara Anggota PBB | Suara Papua.

https://suarapapua.com/2019/09/29/b enny-wenda-tugas-kami-melakukanlobby-pada-negara-negara-anggota$\mathrm{pbb} /$

Usman, B. A. (2017). What Type Of Government Does Vanuatu Have? Retrieved December 2, 2019, from https://www.worldatlas.com/articles/ what-type-of-government-doesvanuatu-have.html 